\title{
MORAL VALUE AND CHARACTER BUILDING EDUCATION IN FOLKLORE: LUBUK EMAS
}

\author{
Silvania Sefaca Sipahutar ${ }^{1}$, Raees Narhan², Ratna Paramita ${ }^{3}$, Yenita Br Sembiring ${ }^{4}$ \\ Universitas Prima Indonesia \\ ${ }^{1}$ silvaniasipahutar@gmail.com, ${ }^{2}$ raees.narhan@icloud.com, ${ }^{3}$ ratnaparamita410@gmail.com, \\ 4yenitasembiring@unprimdn.ac.id
}

\begin{abstract}
The folklore entitled Lubuk Emas is one of the stories that come from North Sumatra, Indone-sia. The aim of this study is the researcher wants to show the importance of moral value and character-building education through the Lubuk Emas folklore. This research used the library research method, where the researcher will gathering information about the moral value and character-building education through Lubuk Emas folklore. The results of this study are to show that the character has a different characterization and also give the reader a different mo-rality include individual morality and social morality. Which later can be applied in everyday life through studying the characters so that the children will grow with a commendable person-ality and character.
\end{abstract}

Keywords: Character Building, Education, Folklore, Lubuk Emas, Moral Value

\section{INTRODUCTION}

Education is currently one of the essential things in the world. Even though education has become a significant need in people's lives, this causes education to be a facilitating process learning, or the acquisition of knowledge, values, skills, habits, beliefs and even the characterbuilding of the students. In educations, the first thing that should be precedence is the knowledge and the character building or the character education of the students. As we know, excellent character education can give fundamental rules of life for grown-ups and young people. It emphasizes the significance of making a difference in children learn and practice behaviors that reflect widespread moral values. Why is character education imperative? Since character education may be a process of learning standard states of mind, convictions, and behaviors that are imperative to have as a responsible citizen, as well as character education to assist children and young people ended up; being conscious of exercising the manners in which are considered as acceptable to the society, it has all to do with arising awareness, commitment, and competence, additionally taking obligation for what they do.

Education and the character-building can be presented in the form of folklore. Folklore can be interpreted as the cultural expression of a community through language that is directly related to various aspects of culture and social value structures of society. In the past, folklore was passed down orally from one generation to the next (Suripan Sadi Hutomo, 1991: 4). Based on the previous research, "Developing the Value of Character Education for Junior High School Students Through Folklore Ngembel Spring Water" and "Character Building Since Early Childhood Through Story Telling About Folklore" state that the folklore can be strengthen the character education for students with their literary works, but not all of the literature works folklore that can strengthen the character education for students. And also the students, children, and the minor one can be able to understand the value and also the moral of the folklore. 
Therefore, the researcher wants to show the importance of moral values and character-building education through folklore titled Lubuk Emas. Lubuk Emas is one of the folklores originating from Indonesia, precisely from the North Sumatra Province. The goal of this study is to define the moral value and character-building in the Lubuk Emas folklore, which later can be used in education to build a civilized character. This research uses a library research method, where the author will gather information about the moral value and character-building education through Lubuk Emas folklore.

\section{Folklore}

Folklore comes from two basic words, namely folk and lore. In step with Alan Dundes (Danandjaja, 2007:1-2), a folk are a bunch of individuals who have physical, social, and cultural identifiers, while lore may be a folk tradition, which is an element of its culture, which is inherited orally or through an example in the course of gesture motion or a reminder helper (mnemonic device). So it is concluded that folklore is: "Some cultures are collective, scattered and hereditary among any reasonably collective, traditionally in numerous versions, both in oral form and in examples in the course of gesture motion or a reminder tool/mnemonic device."

Endraswara's Statement (2010:3) The specificity of folkloric lies in its spread aspect. Meanwhile, Taylor (Danandjaya, 2003:31) Folkloric may be a material that's inherited from tradition, through word of mouth and from the practice of customs. In other words, Folklore is basically a sort of culture that's derived from or inherited orally by generations. The folklore that's often researched is prose folk. in step with Bascom in Danandjaja (2007:50), the story of the people's prose is split into 3 classes, namely myths, legends, folktales.

\section{Moral Value}

The Latin word for moral is mos along with the plurals is mores meaning custom or lifestyles. Talking about moral, generally assume ethics and moral are identical meaning, but within the lifestyle, there are a few contrasts. The moral is accustomed to measure the benefits of occurring, while ethics to check value framework all around done.

According to Hurlock (1977), morals are ethical norms, the idea of life that's promoted by most specific social orders. The moral is expounded to understanding good and bad. Good is taken into account moral, while crime is taken into account immoral behavior. Barcalow (1994) says that morals is analyzed by the activities and possible activities of others, and might be analyzed nearly as good or bad; and feasible or infeasible; mandatory; for bidden or permissible; commendable or answerable.

To grasping qualities, morals are a portion of values, to be specific morality. Moral values are associated with behavior of human around good or evil. This can be a form of belief received by the general public about attitudes, actions, behavior, obligations, morals, and politeness. Awareness of certain great and awful things are relative.It implies that anything that is generally calculated good for somebody might not be good for one more person. An individual's assumption about morals and values is normally affected by the perspective.

In addition, moral values are values related to habits, manners, and behavior. The word "moral" is usually meant permanently as a bad person so that in human life, it is found in the wording of goodness as people in general (Budiningsih; 2004). Roundly, moral education is the norm, and understanding that determines things that are calculated good and bad. Darajat (1977: 8) 
within the book Hurlock's Child Development says that morals are : (1) Behavior that's per social standards and is meted out sincerely by individuals; (2) Responsibility for his or her actions; and Consideration for group peace, while personal desires or benefits are passed on to the opposition who have secondary interests.

Children study good or bad, right and wrong from their parents and other relations or their immediate surroundings. They learn everything they have like learning a way to eat things in a very great way, a way to talk, a way to act etc. And after they are adults, they are going to interact with others who don't seem to be usually relations like neighbors and therefore the community. Children need socialization to search out how they must act amid the community and cultural environment.

Moral values are individuals' convictions and values that adjust to normal principles of what is good and bad also about individuals. Different moral and ethical standards are supported determining standards of right and wrong and supported people's habits or agreements. If people think that some behavior is sweet, then it is also good for his or her values. Moral emerges from human cognizance to create themselves and society, create approaches to address mistakes, and improve what has been good. The moral is that the basis of human existence as a controller of the perfection of life. Moral values rise out of human conscience, which is capable to determine behavior.

\section{Character Building}

An understanding of Character Building concerning language, Character Building, or character is constructed from 2 syllables build (character) and character. Meanwhile, a character may be a behavior, manner, personality, or character which distinguishes one another from others. Module Introduction to characteristic conduct and good behavior supported Pancasila values.

Based on this understanding, it will be argued that character building is going to discuss as follows:

a. Is an ongoing process to shape, character, manner and mental nature supported the spirit of devotion and togetherness.

b. Perfecting the prevailing character for the expected character within the framework of governance and development implementation.

c. Fostering characters that feature characters that are conducive to social, national and state life supported the values of the nation's philosophy of Pancasila.

The purpose of character building is to develop the nation's character to be able to realize the noble values of Pancasila. This character building serves to build up the essential potential to be kind, think well, and behave well; correcting poor behavior and reinforcing good behavior, and separate cultures that are not following the noble values of Pancasila. The scope of character building includes families, education units, civil society, political society, government, the business world, and mass media. Researching moral values and character building in folklore can help children learn things related to moral development, determine what is beneficial and what not to do in their social environment.

\section{METHOD}

In this research, the methodology that the researcher use is Metode Penelitian Kepustakaan or Library Research Methods. Agreeing to M. Nazir in his book entitled 'Research Methods' states 
that what is implied by: "Literature study or library Research Methods is a method of collecting information by conducting studies of books, literature, notes, and reports that have to do with the issue solved." (Nazir, 1988: 111). Mestika Zed (2008) contends that library research utilizes library sources to get research information and he says that library research is solid to answer research problems, he indeed emphasizes that library research is like a gold mine which is exceptionally wealthy for scientific research. Literature study, to be specifically conducting inquire about by studying and reading literature that needs to do with the issues that are the question of research. Which is named library research or literature study is a series of library data collection activities, reading, taking notes, and processing research materials. The researcher uses the document as the source of the data because it is the written material. Subsequently, the data of this study are sentences or utterances containing moral values and character building within the Lubuk Emas Folklore, which is one way to teach moral values in education. The researcher gathering the data with observation and documentation. From the data, the researcher analyzed the moral values and character building of the story LUBUK EMAS, and then the researcher analyzed whether there is a development of these characters and moral values.

\section{RESULTS AND DISCUSSION}

\section{Results}

The results of the study achieved after critical analysis, with documentation and observation of the story carried out, namely, the "Lubuk Emas" folklore from North Sumatra.

Table 1. Characterization of the characters

\section{Characters}

He may indeed be a father who loves and wants to give the
best for his daughter. His attitude is indeed good to build the
character of the readers. However, the way he chooses is not
quite right by forcing his daughter to marry someone who she
doesn't love.

\section{Characterization}

As stated in Lubuk Emas, she is someone who has a kind, tenacious, hardworking, and loyal personality. The character

Sri Pandan of Sri Pandan is stated in the above sentence, which is a good moral character. Unfortunately, she has a short mind and is in a hurry to decide what not to imitate in the formation of moral character and attitude.

Hatoban was a diligent and obedient person. He is also described as someone who is resigned to accept his fate. The Hatoban character of Hatoban is suitable to be used as an example of moral values to build children's character through the folklore. 
Morals value is one of the bases that we make choices - which is right or off-base? good or evil? that can offer aid in progress one's character building. The other based are monetary, convenience, aesthetics (craftsperson), subjective (flipping coins).

Table 2. Individual Morality and Social Morality

\section{Individual Morality}

It provides the assertion for choices Justice is one of the establishments of and judgements through people: law, which makes a difference in genuineness, devotion, great direct society and control personal confidence, existence to be behaviour. The social ethical quality responsible. considers whether an activity debilitates the welfare of society.

\section{Discussion}

"Simargolang, in the middle of the association in his community Simargolang is very favored, not only because of good ethics but also because he knows martial arts. He often hunted into the forest, then the result of his hunt he distributed to the people of his village. His family life and helpful quality encouraged the people in the village to propose that Simargolang be willing to be their leader. We should find a more wise and prudent person, someone who is truly capable of being our leader,"

a. Positive attitudes often get good responses from others, such as the paragraph above Simargolang's attitude that led the villagers to propose him as their leader, because he has good moral values as described in social morality and this can be used as an example in the development of the character of children who have good character and decent human being.

"As is the custom of the king who likes to work hard, he also trains his daughter to work. Sri Pandan has a beautiful face, is also good at weaving mats, making winnow, and making other house jewelry. Together with her peers when pounding rice, the pestle of Sri Pandan seems rhythmic until it is good to hear. Playing around during the full moon of Sri Pandan has always been the focus of her friends' attention because she is easy to get along with and has a sweet voice."

b. The behaviors listed above are examples of character building that are good for children to read because folk tales are taught or told to children at an early age. The moral value contained is the obedience of a child to her father to work hard and become a wise woman in which the behavior is liked by society. 
"Reputedly, Princess Sri Pandan's beauty with her commendable ethics not only gave causing sympathy to the youth of Teluk Dalam village but has also been famous in other areas."

c. As written above, this praiseworthy character raises public sympathy that a child is educated well.

"King Simargolang was wise and prudent even though the proposal had hit the heart yet answered with the words, if Sri Pandan is willingly be married, an envoy will send to Aceh to inform him."

d. Some events in folklore are great examples, but there are bad examples too. As written above the king Simargolang needed to inquire about his daughter about the proposal of the king of Aceh, despite the fact, King Simargolang did not concur that her daughter cherished another man, who was their royal residence worker. Where this behavior is the act of examining which is good and bad as clarified about moral values.

"Father, have mercy on me, that is too late, and the promise has combined. The man is despicable, but the gap of differences in position has been covered with love."

e. The story paragraph above can be a great example of character building how to talk to the parents, although the parents are angry with her. The moral value contained in this paragraph is how a daughter is patient and still speaks respectfully and politely when argue with her father.

"With a trembling lip, the Hatoban said, "My Lord, forgive this despised servant who has dared to love The Princess. Many times I have explained what may have arisen as a result of this relationship, but princess Sri insisted on continuing. Sri Pandan was so relentless, last night after my Lord King and Empress persuaded her, she came to this despised servant explaining the situation. So I keep trying to get Sri Pandan to accept the proposal of the King of Aceh because it concerns the honor and the dignity of My Lord King and this kingdom"

"My lord the King," Hatoban said, "I will be responsible for the death of the princess Sri Pandan. So stop beating me up, but my Lord helps me by asking people to bring tobacco, soak in water and squeeze it over my navel. I will soon to follow my beloved Sri Pandan," he said."

f. Hatoban's character is a character who is diligent and very obedient. But some events are not good to be used as learning moral values and character-building education, which is an act of defencelessness. Notwithstanding, he was sure that his sincerity and honesty could solve all problems including his problems with the king. However, sincerity and honesty are what deserve to be used as learning character and moral values.

"Sometime after the incident, the kingdom of King Simargolang disappeared, people tried to take the gold of the princess. Once upon a time, there was a fisherman who tries to take the gold. The fisherman managed to get it little by little. Because of his greed, even though he already got a lot of gold, he didn't want to stop. Finally, a magpie bird said from the top of the tree, "Gotaphon, ngaloloi" (decide, that's enough), but he ignored it. Finally, disaster came, sampan sank, gold and his sampan swallowed by Lubuk Emas."

g. This paragraph taken from the folklore of Lubuk Emas teaches the reader more precisely the children that the greedy act is un-commendable so that his behavior brings misfortune to himself. That is a great example to use as a medium to learn moral values and build children's character so that they are not avaricious. 
The propensity of storytelling or narrating about folklore must be done at school, particularly at home, so the correspondence among the educators, parents, and children which can be awakened in children's character. Building character through folklore could be a great thought since we jump into the world of children. It is reliable that the children will be more caring and have great character. The results of this study are that folklore is taking from everyday life, can used as a direction or a guide or a collection of knowledge that is in the minds of people's lives in its time (the 19th century) in Sumatra. The folklore that is abstracted is a story that is raised from fictional thoughts and true stories into a flow of life's journey with moral messages that contain the meaning of life and ways of interacting with other creatures. Likewise, folklore can answer the questions of human children about natural phenomena, for which the answer was not sufficiently scientifically known at that time. Folklore also knows the moral messages conveyed, provides messages of meaningful moral knowledge and shapes personality characters, and can form a frame of mind that directs humans to their choices in life.

\section{CONCLUSION}

The conclusion of the study acquired after critical analysis and observation of the story carried out, namely the "Lubuk Emas" folklore from North Sumatra. The result showed the existence of moral values that can learn from that and folklore to build better children's character because folk tales contain a lot of moral messages. Which later can apply in daily life by studying the characters so that the children will grow and develop with a commendable personality and character. Lubuk Emas folklore can use as guidelines in education to create obedient students. Moral values that can be used from the Lubuk Emas Folklore in character building incorporate helping the poor, having good character, being helpful, having inner beauty, being courageous, respecting each other, not overbearing, and being responsible.

\section{ACKNOWLEDGMENTS}

First of all, in the name of God, the most gracious, merciful, and All of the praises who has given us blessings, guidance, because of His graciousness and mercifulness, the writer can write well in this research. Thanks to my family also my friends who have to give support. Thanks to my lecturer who has given much direction, suggestion, motivation, and also has spent his valuable time guiding the researcher to accomplish this research article well.

\section{REFERENCES}

Agustina, I. W., Sutama, I. M., \& Rasna, I. W. (2019). Analysis of Character Educational Values in Folklore and the Relevance in the Formation of Student's Character in Vocational High School. Jurnal Penelitian Dan Pengembangan Sains Dan Humaniora, 3(1), 36-40. https://doi.org/10.23887/jppsh.v3i1.17362

Arikunto, Suharsimi. (1933). Prosedur Penelitian. Bandung: Bina Aksara.

Asri, Budiningsih. (2004). Belajar dan Pembelajaran. Jakarta: Rineka Cipta.

Barcalow, Emmet. (1994). Moral Philosophy. California: Wadsworth Publishing Company. Bertens, K.

Danandjaja, James. (2007). Folklor Indonesia, Ilmu Gosip, Dongeng, dan lain-lain. Jakarta: Grafiti.

Darajat, Zakiah. (1977). Pendidikan Agama dalam Pembinaan Mental. Jakarta: Bulan Bintang.

Elya Susana, (2018). "Moral Value in Charlotte Bronte's Novel Jane Eyre" in the $1^{\text {st }}$ Annual International Conference on Language and Literature, KnE Social Sciences, pages 287294. DOI 10.18502/kss.y3i4.1940 
Ha, P. Le, \& Que, P. Van. (2006). Vietnamese educational morality and the discursive construction of english language teacher identity. Journal of Multicultural Discourses, I(2), 136-151. https://doi.org/10.2167/md038.0

Huriyah, S. (n.d.). Building Character Through Story Telling In Children's Literature.

Hurlock, Elizabeth B. (1991). Psikologi Perkembangan: Suatu Pendekatan Sepanjang Rentang Kehidupan. Jakarta: Erlangga

Kamarudin, S. A. (2012). Character Education and Students Social Behavior. Journal of Education and Learning (Vol. 6).

Ketut Warta, I. (n.d.). Presented for the XIII Annual International Seminar on Ethics.

Kusmana, S., Wilsa, J., Fitriawati, I., \& Muthmainnah, F. (2020). Development of Folklore Teaching Materials Based on Local Wisdom as Character Education, 8(3), 103-109. https://doi.org/10.11648/j.ijsedu.20200803.14

Lestari, T. A., Alphan, A. (2016). Membangun Karakter Berbahasa Santun Pada Anak Melalui Cerita Rakyat "LUBUK EMAS". 326-335.

Mentari, A., Yanzi, H., \& Nopiana. (2020). Character Building Since Early Childhood Through Story Telling About Folklore. https://doi.org/10.2991/assehr.k.200808.008

Mestika zed. 2004. Metode Penelitian Kepustakaan. Jakarta: Yayasan Obor Indonesia.

Moh. Nazir. 2011. Metode Penelitian. Bogor: Ghalia Indonesia.

Nasution, B. H., Rahman, A., \& Daulay, S. (n.d.). Character Based Text for Development on V Grade Students of Elementary School, 3. https://doi.org/10.21009/AKSIS

Naufalia, A. (2020). Character Education in Malin Kundang and Shim Cheong, a Filial Child: A comparative literary study. 424(Icollite 2019), 102-106. https://doi.org/10.2991/assehr.k.200325.062

Perbawani, A., Suwandi, S., \& Subiyantoro, S. (2019). Developing the Value of Character Education for Junior High School Students through Folklore Ngembel Spring Water. European Alliance for Innovation n.o. https://doi.org/10.4108/eai.27-4-2019.2286802

Ramaila, Z. (2005). An investigation of potential role that folklore can play in environmental education: a case study of Mphoko, (November). Retrieved from http://etd.uwc.ac.za/xmlui/handle/11394/1837

Sayer, I. M., Kristiawan, M., \& Agustina, M. (2018). Fairy Tale as a Medium for Children's Character Cooperation Building. Al-Ta Lim Journal, 25(2), 108-116. https://doi.org/10.15548/jt.v25i2.458

Umar, Jacob., dkk. 1982. Cerita Rakyat Daerah Sumatera Utara. Medan: Direktorat Jendral Kebudayaan.

Wahyudin darmalaksana. 2000. Jejak Kuliah Online: Metode Penelitian. Fakultas Ushuluddin UIN Sunan Gunung Djati Bandung. 